\title{
PLANTS
}

\section{NOSTOC, A LITTLE-KNOWN IMPORTANT ALGA IN THE SASKATCHEWAN PRAIRIES}

BERNARD DE VRIES and M.V.S. RAJU, George Ledingham Herbarium, Biology Department, University of Regina, Regina, SK S4S OA2

Nostoc, a common alga, belonging to the division Cyanophyta (blue-green algae) or Cyanobacteria, occurs worldwide in a variety of habitats. ${ }^{5,8}$ It is one of the most common soil algae growing in the native grasslands of Saskatchewan and occurs in disturbed areas, including recreation areas and agricultural fields. ${ }^{2}$ It is also an aquatic alga occasionally seen in shallow lakes in southern Saskatchewan. ${ }^{6}$

The genus Nostoc contains many species, all producing abundant mucilage in which characteristic beaded filaments or trichomes are embedded (Fig. 1B-D). It occurs on soil in open grasslands of the prairies and is morphologically uniform with flat mucilaginous expansions. This species has been identified as Nostoc commune.

Nostoc is one of the common algae associated with filamentous fungi to form lichens (Peltigera polydactyla, a common lichen in the prairies). A lichen is a dual organism made up of a mycobiont (filamentous fungus) and a phycobiont (green or blue-green alga), such as Nostoc, exhibiting the phenomenon of mutualism. About 8 per cent of lichen species are known to contain cyanophycean (blue-green) phycobionts. $^{5}$

On the prairies, Nostoc appears as patches of burnt paper and is found on ground between grass hummocks (Fig. 1A). These patches, technically known as "Nostoc colonies", occur throughout the growing season, but can also be found in winter under snow without showing obvious growth activity. In the growing season, following rain, these patches change to dark yellow or brown, becoming thick and slimy after imbibing water (Fig.1E). Nostoc colonies have the ability to absorb water instantaneously when it rains, and can also retain water. However, the mucilaginous mass with imbedded algal filaments will desiccate during prolonged dry periods, becoming once again a dry papery structure, often seen in dry grasslands.

In the summer of 1999, the distribution of Nostoc colonies in the disturbed grassy areas around Wascana Lake, in Regina, was investigated. A survey was conducted on banks situated between Wascana Lake and the University of Regina Campus, an area designated to become a part of the Regina Plain Native Prairie Restoration Project in the city. This area is predominantly vegetated by Crested Wheatgrass (Agropyron cristatum (L.) Gaertn.) and Brome Grass (Bromus inermis Leyss.) and is highly disturbed by trampling, yearly mowing, etc. Twenty quadrats of 100 square meters each were selected to determine the abundance of Nostoc colonies. Although some lichens were 


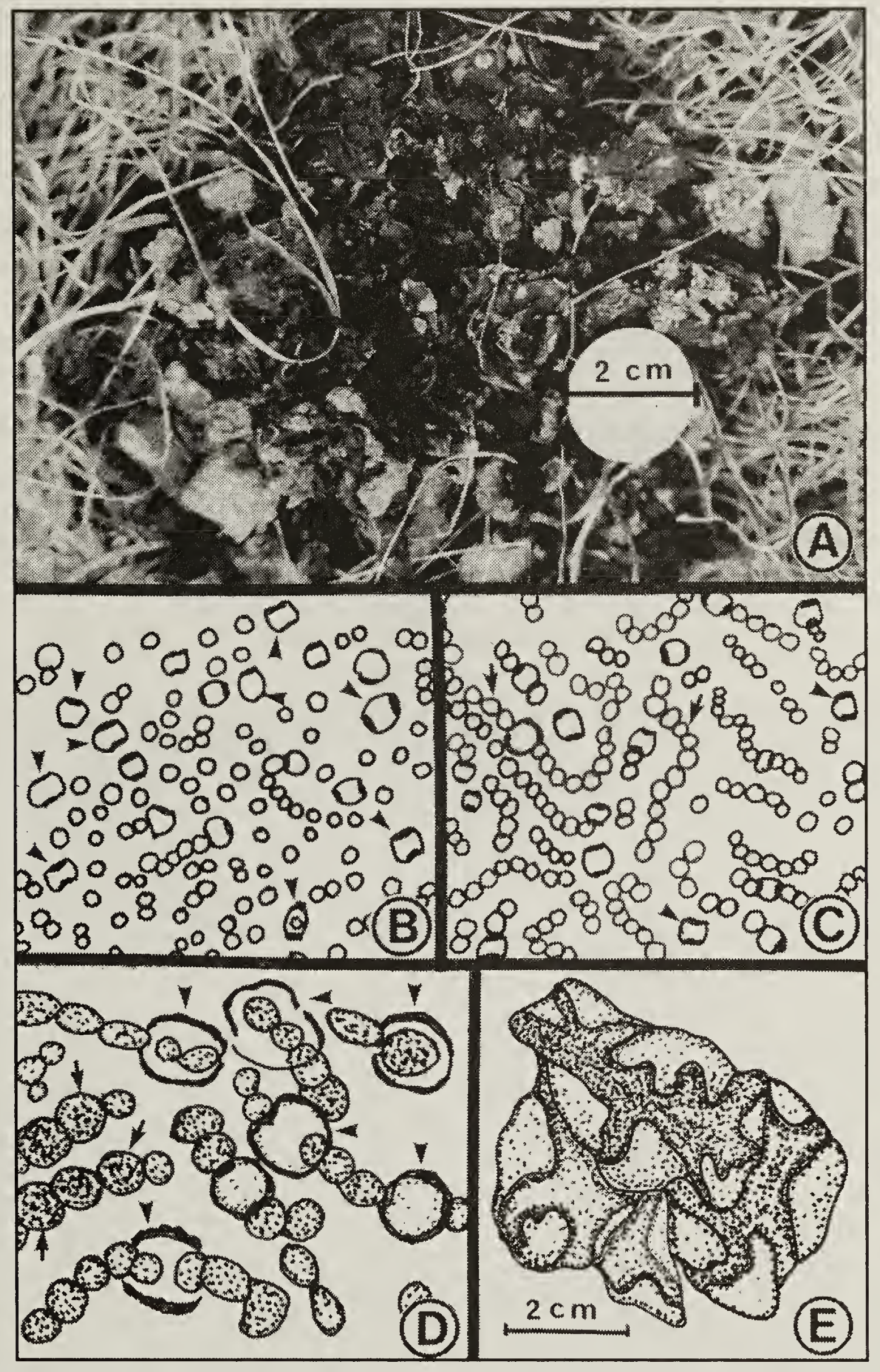

Figure 1. Nostoc - Habit and structure of the alga collected late in the Fall. A. Dried colony of Nostoc to show the habit consisting of brittle flakes of the alga embedded in dried mucilage. B. Dried colony soaked in water for a day and examined under low magnification. $x$ 10. Note the diffusely distributed cells and the cell types and also some broken filaments. Arrow-heads point at heterocysts. $x$ 40. C. The same colony, 4-days old in water with longer filaments. Arrows point at extended filaments and arrow-heads at heterocysts. $\times 40$. D. Filaments from thallus of colonies soaked in water for several weeks. Note heterocysts (arrow-heads) and newly formed akinetes in filaments (arrows). X 80. E. A piece of water-imbibed thallus in water for about 5 weeks has thickened and curled up. It is different from fig. $1 A$. Scale is $2 \mathrm{~cm}$. 
present in the area, they were not included in this study.

Results showed that there was a mean number of $8.35 \pm 1.42$ (standard deviation) independent Nostoc colonies with a mean algal area of $68.35 \pm 13.14$ (standard deviation) $\mathrm{cm}^{2}$ per quadrat. The conversion of the area into square meters gives the occupied area of the alga $0.007 \mathrm{~m}^{2}$ per $100 \mathrm{~m}^{2}$.

Nostoc species, like other members of the Cyanophyta, are ecologically significant because they are able to fix atmospheric nitrogen, converting it into nitrogen compounds. ${ }^{3,7}$ The atmosphere, besides other gases, contains about $80 \%$ elemental nitrogen, which plants cannot use. In addition to nitrogen compounds, some carbohydrates and proteins are also released from Nostoc colonies, thereby enriching the soil. Nitrogen input into this ecosystem is likely trivial because of the small amount of Nostoc present but is important in natural prairies. According to one study in the Sand Hills Grasslands, a large natural prairie in south west Nebraska extending into South Dakota, the freeliving and lichenized cyanophyte (mostly with Nostoc) colonies together covered $12-29 \%$ of surface area and contributed considerably to nitrogen fixation. ${ }^{4}$ Their importance in soil fertility is substantial and well documented. ${ }^{4,10}$ In native prairie grassland of Saskatchewan, many algae and bacteria are known to contribute to soil fertility, and Nostoc is one. $^{2}$

In many parts of the world, especially in the humid tropics and subtropics, some species of Nostoc can grow luxuriantly into large mucilaginous flakes or balls ( $1-5 \mathrm{~cm}$ in diameter). ${ }^{5,8}$ In China and Japan, they are considered edible and a delicacy. In some parts (India and Israel) Nostoc and other closely related genera have been used extensively to reclaim parts of deserts for cultivation. ${ }^{3,5,8}$ Some members of the Cyanophyta including Nostoc form dense mats that are known to help maintain moisture content $(8.9 \%)$ of soil better than without them $(1.3 \%)$ and to prevent soil erosion in deserts. ${ }^{1,4}$

Nostoc and other members of the Cyanophyta are regarded as the most primitive "plants" on earth. ${ }^{9}$ They have survived evolution for millions of years without losing their unique cell-structure and the ability to photosynthesize and to fix atmospheric nitrogen. No wonder they are, as a group, ubiquitous and distinct!

1. Booth, W.E. 1941. Algae as pioneers in plant succession and their importance in soil erosion control. Ecology 22:3846.

2. Coupland, R.T. 1973. Algae and Moss Populations in Soil. Technical report No.23, pp. 1-31. International Biological Program, University of Saskatchewan, Saskatoon, Canada.

3. Friedman, E.I., Y. Lipkin and R. Ocamo-Paus. 1967. Desert Algae of the Negev (Israel). Phycologia 6:185-200.

4. Kaputska, L.A. 1987. Dinitrogen fixation by cyanobacteria and associate rhizosphere bacteria in the Arapho prairie in the Sand Hills of Nebraska. American Journal of Botany 74:107-113.

5. Lee, R.E. 1989. Phycology. $2^{\text {nd }}$ Ed. Cambridge University Press, New York.

6. Raju, M.V.S., D. Young and J. E. Hines. 1971. A check-list of algae in Wascana Lake. Blue Jay 29:215-216.

7. Round, F.E. 1981. The Ecology of Algae. Cambridge University Press, London. 
8. Sharma, D.P. 1986. Text Book of Algae. Tata McGraw-Hill Publishing Company, New Delhi.

9. Schopf, T.W. and M.R. Walter. 1982. Pp.543-564. In:Carr, N.G. and Whitton, B.A. (eds.) The Biology of the Cyanobacteria. The University of California Press, Berkelely, California.

10. Woodmansee, R.E. 1979. Factors influencing input and output of nitrogen in grasslands. Pp. 117-134. In: French, N.R. (ed.). Perspectives in Grassland Ecology. Springer-Verlag, New York.

\section{NEW VASCULAR PLANT FINDS AT THE RENDEK ELM FOREST}

DIANA BIZECKI ROBSON, 811 Avenue E North, Saskatoon, SK S7L 1 S7 and VERN HARMS, 212-115 Keevil Crescent, Saskatoon, SK S7N 4P2



Figure 1. Garth Nelson leading a group in the Rendek Elm Forest Nature Sanctuary. Mr. Rendek, second from right. 